\title{
SIGNAL RESOLUTION POLY-GAUSSIAN ALGORITHM FOR NON-GAUSSIAN INTERFERENCE SIMULATION MODELING
}

DOI: |0.36724/2072-8735-2020-|4-3-4|-46

Renat F. Zaripov,

Kazan National Research Technical University named

after A.N. Tupolev-KAl, Kazan, Russia,

renat.zaripov@gmail.com

Marat M. Fatykhov,

Kazan National Research Technical University named

after A.N. Tupolev-KAl, Kazan, Russia,

marat.fatykhovs@gmail.com

Keywords: simulation modeling environment, non-Gaussian channels, signal resolution algorithm, Matlab

The effective use of the code division multiplexing communication systems channel resource requires the new solutions for conflict-free and high-quality reception and transmission of mixed traffic under the conditions of an exponential increase in the number and density of wireless network subscribers, in particular, those who use multiservice services. At the signal transmission channel layer this problem is solved by applying mathematical models adequate to the real signal-noise environment and algorithms for receiving noise-like signals in dynamic jamming mixtures, which provide increased noise immunity, system capacity and having acceptable computational complexity (technical feasibility of signal processing devices), which is extremely important. In practical applications, the system model includes a parametric quasi-stationary channel, a random number of quasi-determined signals and randomly fluctuating interferences, which determines the real signal-noise situation in the communication system radio interface operational area.In this article, scientific and engineering problems related to the use of software for complicated interference cases secondary signal processing, particularly algorithms based on post-correlation synthesis and analysis technology, are considered. The original simulation software modules are described, which allows to compensate inaccuracy and modeling errors that occur when traditional visual and imitative mathematical modeling tools are applied.

Information about authors:

Renat F. Zaripov, assistant, Kazan National Research Technical University named after A.N. Tupolev-KAl, Department of Nanotechnology in Electronics, Kazan, Russia

Marat M. Fatykhov, assistant, Kazan National Research Technical University named after A.N. Tupolev-KAl, Department of Nanotechnology in Electronics, Kazan, Russia

Для цитирования:

Зарипов Р.Ф., Фатыхов М.М. Моделирование полигауссового алгоритма разрешения сигналов в негауссовских помехах // Т-Сотт: Телекоммуникации и транспорт. 2020. Том 14. №3. С. 4 I-46.

For citation:

Zaripov R.F., Fatykhov M.M. (2020) Signal resolution poly-gaussian algorithm for non-gaussian interference simulation modeling. T-Comm, vol. 14, no.3, pp. 4I-46. (in Russian) 


\section{Introduction}

A number of modern investigations in the field of wireless communication networks electromagnetic environment shows that real probability distributions of desired and interfering signals in the off-hook and free channels are non-Gaussian (including poly-modal cases).

Nowadays, a number of optimal and quasioptimal algorithms for randomly fluctuating signals and interferences receiving and processing designed [1-10]. But technically "simple" selfadaptive algorithm development is challenging issue. This algorithms must support fast corrective adjustment for group signal secondary processing at the interval of one or several data frames.

The development and simulation of noise-tolerant signal processing algorithms in a complex of noise and interference with diverse probabilistic distributions adequate to the real situation in the radio channel is an urgent scientific and practical task and is directly associated with quite a lot of labor in the preparation, program description and modeling of the transmitting part of the system, radio channel, and receiving part with adequate verification of simulation results. Usually, the typical software of this level simulator developers is aimed at solving a narrow problem and its sources are restricted, which does not allow system model and the executable algorithm structure quick parameters change.

In most cases, the mathematical description of the radio channel in solving such problems is significantly simplified and does not take into account their complexity associated with variation of the signal-interference environment parameters, radio signals multipath wave propagation and fading, the "near-far" problem, the influence of mutual interference with the signal structure, the fluctuation noise, industrial and other types of interference influence, etc. $[11,12]$.

This paper presents a specialized program for simulation and mathematical modeling of well known, including poly-Gaussian, signal processing algorithms in mobile communication systems, based on the MatLab language and taking into account the drawbacks inherent in both visual modeling tools and the programming language itself [13].

The available modeling tools subsequently allow multidimensional processing of random signals and interference.

\section{Investigated model of communication system}

As an example, consider a communication system at the observation time $\left[0, \mathrm{~T}_{\mathrm{obs}}\right]$, in which we have $\mathrm{N}$ active user terminals. Each user has his own probability $\mathrm{P}_{\mathrm{N}}$ of being active with duration of message $\left[0, \mathrm{~T}_{b}\right]$. Considering that at the observation time $\left[0, T_{\mathrm{obs}}\right]$, base station (BS) detects random number of information bits, that are multiplexed with OVSF codes to get direct sequence spread spectrum (DSSS).

A single bit of information $b_{k}$, where $k=\overline{1, K}$ (where $K$ is a index number of bit in the message) is processed as a code bit, passed through procedure of protective coding, and, for phase manipulation, transformed into bipolar form, i.e. «1»=«-1», a $\ll 0 »=\ll 1 »$.

In general, received group signal at the entrance can be described as:

$$
r(t)=s_{k}(t)+n(t)+l_{z}(t)
$$

where $s_{k}(t)$ are signals of number of active user terminals after amplification and carrier transfer; $n(t)$ - additive white Gaussian noise with zero mean $\left(\mathrm{m}_{\mathrm{n}}=0\right)$ and randomly specified variance $\left(\sigma_{n}^{2}\right) ; l_{z}(t)$ - uncpecified random process caused by different types of noises and interferences, such as industrial noise, internal system and chaotic pulse interference. This is non-Gaussian interference random number of signals resolution problem formulation. The generalized block diagram for the considered and simulated communication system is presented in Fig. 1.

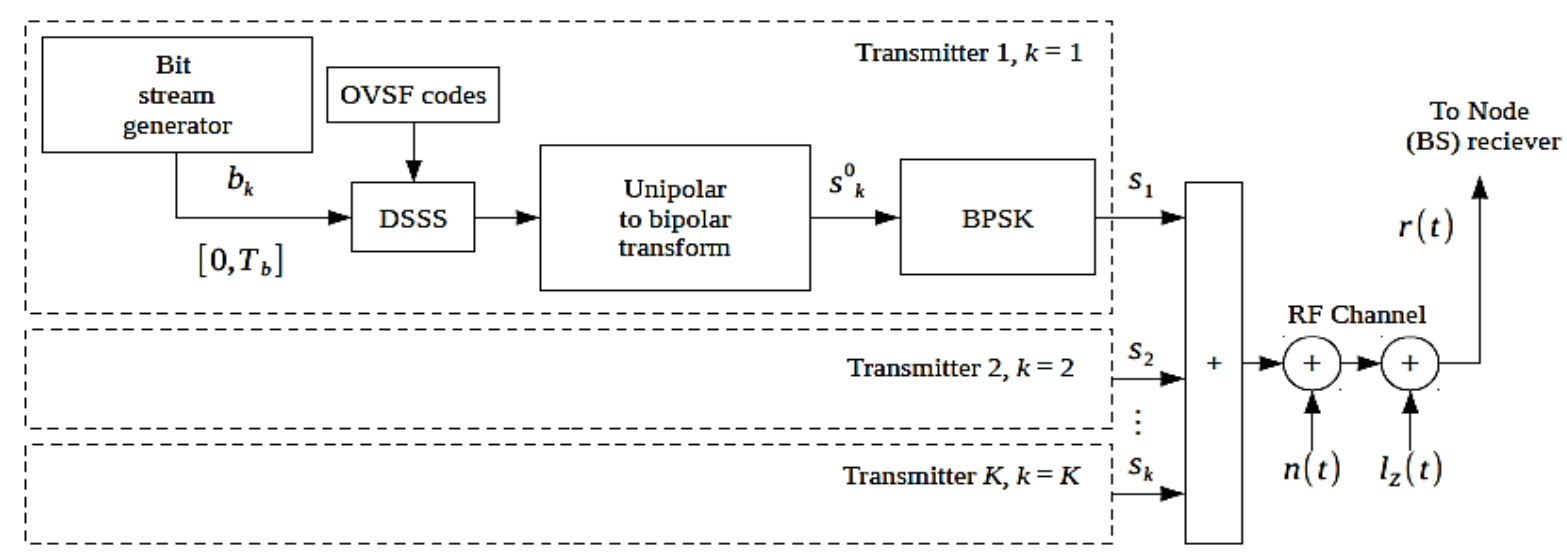

a)

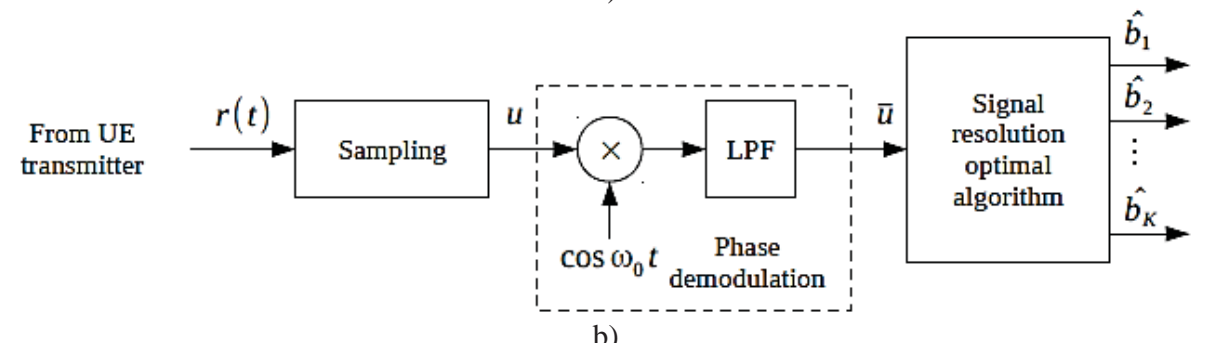

b)

Fig. 1. Communication system model: a) structure of a transmitter and a communication channel; b) structure of a receiver 
There are few limitations and assumptions for considered system model

1. It is assumed that at the observation interval active user terminals synchronization procedure is provided. This leads to, delay estimates are not performed additionally for each signal.

2. For rec ver, every type of interferences appears as polyGaussian interference, represented by the weighted sum of $\mathrm{z}$ Gaussian composition components [14], whose parameters are known at the frame observation interval from the use of the EMalgorithm [9].

3. ommunication system model is based on the determined signal receiving, and the random nature of input process fluctuations determined by signal and interference mixture polyGaussian probabilistic model [15].

\section{Optimal signal resolution algorithm}

In [1] an algorithm for resolving signals was proposed and an analytical calculation of likelihood ratios for one signal and interference group was performed. It is proposed, as an example, to modify the specified algorithm and the resulting expressions and analytically decompose them into separate components according to the hierarchical computational tree used in computational clusters of procedures in the modeling process.

We formalize this problem in terms of statistical hypotheses testing. At the input of the receiver there is a signal of the following form: $u=S_{N}+I_{M}+n$ (hypotesis $S_{N} I_{M} n$ ), or $u=n u=n$ (hypotesis $n$ ).

Probabilistic description of hypotheses has the form:

$$
\mathrm{S}_{\mathrm{N}} \mathrm{I}_{\mathrm{M}} \mathrm{n}: W\left(u \mid \mathrm{S}_{\mathrm{N}} \mathrm{I}_{\mathrm{M}} \mathrm{n}\right)=\prod_{n}^{[N]} q_{S_{n}} \prod_{m}^{[M]} q_{I_{m}} G\left\{u ; \sum_{n}^{[N]} S_{n}+\sum_{m}^{[M]} I_{m} ; \sigma_{I_{M} n}^{2}\right\} \text {, }
$$

$$
n: W(u \mid \mathrm{n})=G\left\{u ; 0 ; \sigma_{n}^{2}\right\}
$$

where $\sigma_{I_{M} n}^{2}=\sigma_{N}^{2}+\sum_{m}^{[M]} \sigma_{I_{M}}^{2} ; G$ is Gaussian density function; $q_{S_{n}}$ is a probability mix weight for $N$ signals; $q_{I_{m}}$ is probability mix weight for $M$ interferences; $N$ - vector string of signal numbers (for example $[\mathrm{N}]=\left[\begin{array}{lll}1 & 4 & 6\end{array}\right]$, 1st signal, 4th signal and 6th signal); $M-$ vector string of interference numbers (for example $[\mathrm{M}]=[1$ $24], 1$ st interference, 2nd interference and 4th interference); $S_{n}$ and $I_{n}$ are the mean of $n$-th signal and $m$-th interference correspondingly.

In this case likelihood ratio has form:

$$
l_{\mathrm{S}_{\mathrm{N}} \mathrm{I}_{\mathrm{M}}^{\mathrm{n}}}=\prod_{n}^{[N]} q_{S_{n}} \prod_{m}^{[M]} q_{I_{m}} \frac{w\left(u \mid\left\{S_{1}, S_{2}, \ldots, S_{n}\right\},\left\{I_{1}, I_{2}, \ldots, I_{M}\right\}, n\right)}{w(u \mid n)}
$$

Eq. (4) shows that the likelihood ratio calculation unit has high computational redundancy in the computational cluster, therefore, the likelihood ratio finding algorithm requires optimization in the computational part.

Accordingly, the final expression for the likelihood ratio and its components in accordance with [1] is:

$$
l_{\mathrm{S}_{\mathrm{N}} \mathrm{I}_{\mathrm{M}} \mathrm{n}}=l_{0 \mathrm{~S}_{\mathrm{N}} \mathrm{I}_{\mathrm{M}} \mathrm{n}}+Z_{\mathrm{S}_{\mathrm{N}} \mathrm{I}_{\mathrm{M}} \mathrm{n}}(u)+0,5 E_{\mathrm{S}_{\mathrm{N}} \mathrm{I}_{\mathrm{M}} \mathrm{n}}(u)-0,5 E_{\mathrm{S}_{\mathrm{N}} \mathrm{I}_{\mathrm{M}} \mathrm{n}} \text {. }
$$

Here and after

$$
\begin{aligned}
& l_{0 \mathrm{~S}_{\mathrm{N}} \mathrm{I}_{\mathrm{M}}^{\mathrm{n}}}=\ln \left(\prod_{n}^{[N]} q_{S_{n}} \prod_{m}^{[M]} q_{I_{m}} \sqrt{\frac{\sigma_{n}^{2}}{\sigma_{n}^{2}+\sum_{m}^{[M]} \sigma_{n_{m}}^{2}}}\right) ; \\
& Z_{\mathrm{S}_{\mathrm{N}} \mathrm{I}_{\mathrm{M}}^{\mathrm{n}}}(u)=u \frac{\sum_{n}^{[N]} S_{n}+\sum_{m}^{[M]} I_{m}}{\sigma_{n}^{2}+\sum_{m}^{[M]} \sigma_{n_{m}}^{2}} E_{\mathrm{S}_{\mathrm{N}} \mathrm{I}_{\mathrm{M}} \mathrm{n}}=\frac{\left(\sum_{n}^{[N]} S_{n}+\sum_{m}^{[M]} I_{m}\right)^{2}}{\sum_{m}^{[M]} \sigma_{n_{m}}^{2}+\sum_{m}^{[M]} \sigma_{n_{m}}^{2}}, \\
& E_{\mathrm{S}_{\mathrm{N}} \mathrm{I}_{\mathrm{M}} \mathrm{n}}(u)=u^{2} \frac{\sigma_{n}^{2}+\sum_{m}^{[M]} \sigma_{n_{m}}^{2}}{\sigma_{n}^{2}} \text { where } Z_{\mathrm{S}_{\mathrm{N}} \mathrm{I}_{\mathrm{M}} \mathrm{n}}(u) \text { is correla- }
\end{aligned}
$$

tion of input and $N$ signals, normalized on power of noise and $M$ interferences; $E_{\mathrm{S}_{\mathrm{N}} \mathrm{I}_{\mathrm{M}} \mathrm{n}}$ is mutual energy of $M$ interferences, normalized on $\sigma_{I_{M} n}^{2} ; E_{\mathrm{S}_{\mathrm{N}} \mathrm{I}_{\mathrm{M}^{n}}}(u)$ is a cross-correlation of input energy and energy of noise and $M$ interferences.

The resulting formula describes the case of a one sample of the input implementation one-dimensional distribution. In case of $k=\overline{1, K}$ samples, we have:

$$
l=l_{0 \mathrm{~S}_{\mathrm{I}_{\mathrm{M}} \mathrm{n}}}+\sum Z_{\mathrm{S}_{\mathrm{N}} \mathrm{I}_{\mathrm{M}} \mathrm{n}}(\bar{u})+0,5 \sum E_{\mathrm{S}_{\mathrm{N}_{\mathrm{M}}^{\mathrm{n}}}}(\bar{u})-0,5 \sum E_{\mathrm{S}_{\mathrm{N}} \mathrm{I}_{\mathrm{M}} \mathrm{n}},
$$

where $\bar{u}=\left\{u_{1}, u_{2}, \ldots, u_{k}\right\}$.

Rewrite expression (6) in a simplified form for calculation:

$$
l=\underbrace{l_{0}}_{\text {Scalar }}+\sum_{k=1}^{K} u_{k} \underbrace{S l_{\sigma_{k}}}_{\text {Vector }}+0,5 \sum_{k=1}^{K} u_{k}^{2} \underbrace{\sigma_{\mathrm{I} / \mathrm{n}}}_{\text {Scalar }}-0,5 \sum_{k=1}^{K} u_{k} \underbrace{S l_{\sigma_{k}}^{2}}_{\text {Vector }},
$$

and see that $l_{0}, S l_{\sigma_{k}}, \sigma_{\mathrm{I} / \mathrm{h}}$ and $0,5 \sum_{k=1}^{K} S l_{\sigma_{k}}^{2}$ changes only when changing the value of a parameter, for example, after after processing the input implementation by the EM clustering algorithm [16, 17]:

$$
\begin{aligned}
& l_{0 \mathrm{~S}_{\mathrm{N}} \mathrm{I}_{\mathrm{M}} \mathrm{n}}=\ln \left(q_{\mathrm{S}_{\mathrm{N}} \mathrm{I}_{\mathrm{M}} \mathrm{n}} \sqrt{\frac{\sigma_{n}^{2}}{\sigma_{I_{M} n}^{2}}}\right), S l_{\sigma_{k}}=\frac{S_{N_{k}} I_{M}}{\sigma_{I_{M} n}}, \sigma_{\mathrm{I} / \mathrm{In}}=\frac{\sigma_{I_{M}}}{\sigma_{I_{M} n} \sigma_{n}^{2}}, \\
& S l_{\sigma_{k}^{2}}=\frac{\left(S_{N_{k}} I_{M}\right)^{2}}{\sigma_{I_{M} n}} ; q_{\mathrm{S}_{\mathrm{N}} \mathrm{I}_{\mathrm{M}} \mathrm{n}}=\prod_{n}^{[N]} q_{S_{n}} \prod_{m}^{[M]} q_{I_{m}} ; \\
& S_{N_{k}} I_{M}=\sum_{n}^{[N]} S_{n_{k}}+\sum_{m}^{[M]} I_{m} ; q_{I_{M}}=\sum_{m}^{[M]} \sigma_{I_{m}}^{2} .
\end{aligned}
$$

\section{Software simulation complex for mobile communication systems signal processing algorithms modeling}

For simulation of the optimal and quasi-optimal signal resolution algorithms, a software-simulation complex has been developed [13], in which all program elements are made in the form of specialized functional modules. MatLab platform and language were used as a programming language and development environment. MatLab platform runs on 2 engines. 
The first is responsible for mathematical calculations written in $\mathrm{C}++$ using the Runtime library from Microsoft Corporation, the second is responsible for outputting all graphical objects written in Java using the Oracle library from Oracle Corporation. Since MatLab is based on two platforms that most developers use, software written in this environment can be transferred to other object-oriented languages. To increase the speed of calculations, a proprietary database management system was developed.

The developed software system allows to significantly save the time spent by developers on creating an environment of simulation modeling adequate for real signal-interference situations and to evaluate the effectiveness of the synthesized signal and interference processing algorithms. Signal processing algorithms modeling time saving is achieved by:

1. Using a simulation automation method.

2. Use f a program modules code special structure.

3. Optimization of memory usage by a database in a cellular form. This makes it possible not to switch to 64-bit architecture and not to acquire specialized equipment for performing design work. Due to the use of a small amount of memory, the access time is reduced; this leads to a significant increase in the speed of calculations in simulation.

4. Combinations of discrete-continuous values with discrete ones. The essence of this approach is to process data containing information about the time instants of each element of the array. This is necessary when modeling quasi-real communication channels.

5. El ination of the remainder of the division. This problem is widespread in time-dependent process modeling. Most software solutions have libraries that cut off the remainder after the division operation. But, in particular, MatLab does not perform this procedure and returns a value with the remainder. For example, in MatLab, the expression 1/1099 = 1.0000e-99 will not always be true.

6. Using the developed software module for quasi-real communication channels modeling. This program module, through the use of mixtures of different probability distribution densities, makes it possible to simulate quasi-real noise and interference, fast and slow fading of channels, chaotic impulse interferences, simulations of Doppler signal shifts, reduction and increase in wavelength, which cause intersymbol interference and other destabilizing factors.

\section{Results of simulation modeling}

In the Fig. 2., the results of minimizing the mean square error (MMSE) and poly-Gaussian (PG-MMSE) synthesized algorithm asymptotic efficiency and the bit error probability under nonGaussian interference numerical modeling are presented. Modeling conditions: average number of users: 10; OVSF 127 codes used; sufficient statistics - over 1000 frames with a length of 128 bits; equality of received signals energies (when using power control). The parameters of arbitrary non-Gaussian interference were randomly selected from the following ranges: number of probability components: $3-8$, components weighting coefficients: $0.15-0.8$ (under the normalization condition), standard deviation: 0.5-4.5, mathematical expectation: 0-5.

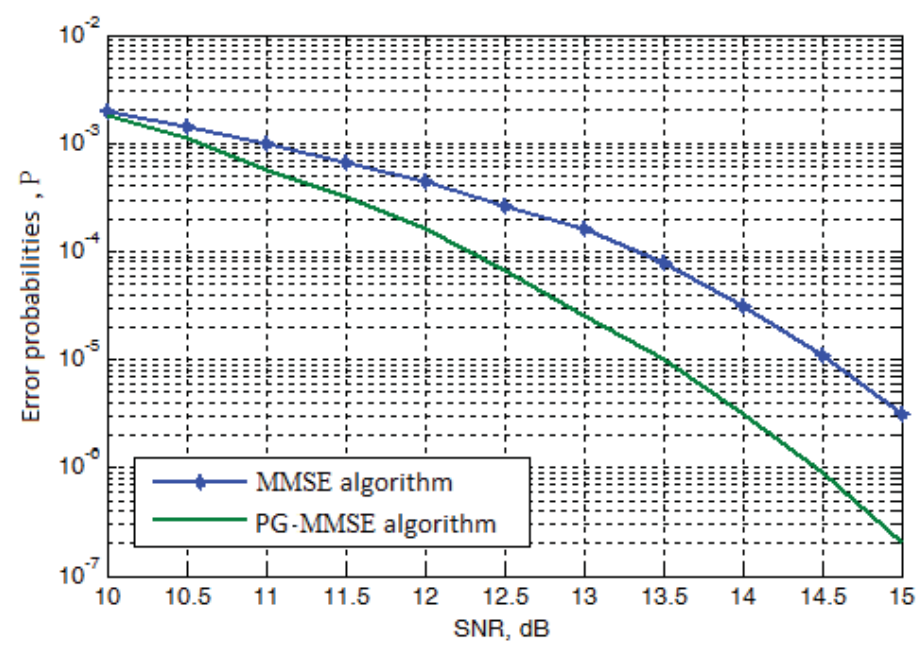

Fig. 2. Bit error probability as a function of SNR

The presented results of mathematical modeling shows a real gain in the noise immunity of the poly-Gaussian algorithm with respect to the well-known MMSE algorithm by almost a decade with equal signal/noise or signal/(interference+noise) ratios.

\section{Conclusions}

The modeled original algorithm for resolving signals in nonGaussian interference is a quasi-optimal signal processing algorithm in which the decision on the signal-noise combination is made according to the maximum likelihood criterion. The algorithm shows the high performance for receivers in channels with non-Gaussian interference.

The disadvantage of the poly-Gaussian algorithm is high computational complexity, more precisely, with an increase in the number of users and interference components, the number of hypotheses increases exponentially. It should be noted that the complexity of the calculations is noticeable against the background of an increasing number of communication systems users. This requires the controlled avoidance of optimality for quasi-optimal procedures development.

However, an undoubted advantage is a limited set of standard operations of no more than 2nd order. Given the modification of the algorithm, an increase in efficiency is also observed in the calculation part. In general, this gives technical simplification when implementing the algorithm on modern FPGAs.

The materials presented in this article and the development of a modeling environment were supported by the Ministry of Education and Science of the Russian Federation as part of scientific research on state assignment, project No. 3469.

\section{References}

1. Kadushkin, V. V. (2016), "CDMA systems non-Gaussian channel optimal receiving algorithm considering intersystem interference." ["Algoritm optimal'nogo priema v negaussovskih kanalah CMDA sistem s uchetom vliyaniya vnutrisistemnyh pomekh"], Zhurnal radioelektroniki, No11, available http://jre.cplire.ru/jre/nov16/index.html. 
2. Lerner I. M. and Il'in G. I. (2017), "Possibility of increasing the data transmission rate in the presence of destabilizing factors in communication systems using symbols with mutual interference", Physics of Wave Processes and Radio Engineering Systems, No.4. pp. 24-34.

3. Lerner I.M. (2017). Method for capacity estimation of real communicational channels with psk-n-signals in presence of ISI and its application. T-Comm, vol. 11, no.8, pp. 52-58.

4. Lerner I.M. and Chernyavskii S.M. (2018), "Capacity estimation of real communicational channels with APSK-N-signals in presence of ISI", T-Comm, No.4, pp. 48-55.

5. Lerner, I.M., Fayzullin, R.R. and Chernyavskii, S.M. (2018), "To a Matter of Increasing the Spectral Efficiency of Phase RadioTechnical Data Transmission Systems Operating under Strong Intersymbol Interference", Russian Aeronautics, Vol.61, No.1, pp. $120-126$

6. Lerner I. M., Fatyhov M.M. and Il'in G. I. (2019), "To the matter of improving the efficiency of communication channels with moving objects using APSK-N-signals", Physics of Wave Processes and Radio Engineering Systems, No.1, pp. 36-49.

7.Lerner I.M. (2019). "To the matter of optimization of the amplitude-frequency responses of communication channels with PSK-nsignals based on the theory of resolution time", T-Comm, vol. 13, No.9, pp. 36-49.

8. Lerner I.M. (2019). "Influence of the shape of the amplitudefrequency response on the capacity of communication channel with memory using APSK-N signals, which implements the theory of resolution time". T-Comm, vol. 13, no.10, pp. 45-59.

9. Kadushk , V.V., Fatyhov, M.M., Zaripov, R.F. (2016) "Sufficiency of a poly-Gaussian approximation of arbitrary probability distributions in the communication systems with mobile objects radio links", New Technologies, Materials and Equipment of the Russian Aerospace Industry: All-Russian Scientific and Practical Conference with International Participation, Collection of reports. Volume 2 ["O dostatochnosti poligaussovoj approksimacii proizvol'nyh veroyatnostnyh raspredelenij $\mathrm{v}$ radioliniyah sistem svyazi s podvizhnymi ob'ektami." Novye tekhnologii, materialy i oborudovanie rossijskoj aviakosmicheskoj otrasli: Vserossijskaya nauchno-prakticheskaya konferenciya s mezhdunarodnym uchastiem,: Sbornik dokladov. Tom 2.] Izd-vo Akademii nauk RT, Kazan, pp. 521-523.
10. Kozlov, . (2014), New mixed approaches to the communication systems radio interface design [Novye smesevye podhody $k$ proektirovaniyu radiointerfejsa sistem svyazi], OOO «Novoe znanie», Kazan, 132 p.

11.Fajzullin, R.R. (2011), An integrated approach to solving the mobile infocommunication systems signals processing multiprocessor devices structural synthesis problem ["Kompleksnyj podhod k resheniyu zadachi strukturnogo sinteza mul'tiprocessornyh ustrojstv obrabotki signalov mobil'nyh infokommunikacionnyh sistem"] Nelinejnyj mir, Vol. 9. No 2, pp. 78-85.

12. Fa llin, R.R., Kadushkin, V.V., Zaripov, R.F. (2015), PolyGaussian algorithm for mobile communication systems channels joint demodulation-decoding [Poligaussovskij algoritm sovmestnoj demodulyacii-dekodirovaniya $\mathrm{v}$ kanalah mobil'nyh sistem svyazi] Nelinejnyj mir, Vol.13. No 8, , pp. 4-9.

13. Zaripov R.F., zullin R.R., Fatykhov M.M. and Kaduskin V.V. KNRTU-KAI. (2017), Programma dlya modelirovaniya algoritmov obrabotki signalov v mobil'nyh sistemah svyazi [A program for simulation of signal processing algorithms in mobile communication systems], Russian Federation, Patent № 2017615223.

14. Chabda , Sh.M., Trofimov, A.T. (1975), Poly-Gaussian representations of arbitrary interference and receiving of a discrete signals [Poligaussovy predstavleniya proizvol'nyh pomekh i priem diskretnyh signalov] Radiotekhnika i elektronika, Vol.20. No.4. pp.734-745.

15. Ch arov, Sh.M., Fajzullin, R.R., Nadeev, A.F., Rahimov R.H., Feoktistov A.Yu. (1997), Statistical models and signal processing techniques in wireless communication systems [Statisticheskie modeli i metody obrabotki signalov $v$ sistemah radiosvyazi: Uchebnoe posobie] Izd-vo Kazan. gos. tekhn. un-ta. Kazan 1997. 90 p.

16.Korolev, V.Yu. (2007) The EM algorithm, its modifications, and their application to the probability distributions mixtures separating problem. Theoretical review [EM-algoritm, ego modifikacii $i$ ih primenenie $k$ zadache razdeleniya smesej veroyatnostnyh raspredelenij. Teoreticheskij obzor], IPI RAN, Moscow, 94 p.

17. Nadeev, A.F., Podkur , I.A. (2015), "Adaptive estimation of non-Gaussian interference distribution parameters based on the application of the EM algorithm and its modifications", ["Adaptivnaya ocenka parametrov raspredeleniya negaussovskih pomekh na osnove primeneniya EM-algoritma i ego modifikacij".] Nelinejnyj mir, Vol. 13. No 8, pp. 64-72. 


\section{МОДЕЛИРОВАНИЕ ПОЛИГАУССОВОГО АЛГОРИТМА РАЗРЕШЕНИЯ СИГНАЛОВ В НЕГАУССОВСКИХ ПОМЕХАХ}

Зарипов Ренат Фаридович, Казанский национальный исследовательский технический университет им. А.Н. Туполева - КАИ, Казань, Россия, renat.zaripov@gmail.com

Фатыхов Марат Монирович, Казанский национальный исследовательский технический университет им. А.Н. Туполева - КАИ, Казань, Россия, marat.fatykhovs@gmail.com

\section{Аннотация}

Рассмотрены научно-инженерные задачи, касающиеся применения программных комплексов для моделирования алгоритмов вторичной обработки сигналов в сложных помеховых комплексах, в частности, алгоритмов, основанных на технологии посткорреляционного синтеза и анализа. Изложены оригинальные модули ПО для имитационного моделирования, позволяющие скомпенсировать погрешности и ошибки моделирования, возникающие при применении традиционных средств визуального и имитационного математического моделирования.

Ключевые слова: среда имитационного моделирования, негауссовские каналы связи, алгоритм разрешения сигналов, Маtlab.

\section{Литература}

І. Кадушкин В.В. Алгоритм оптимального приема в негауссовских каналах СМDA систем с учетом влияния внутрисистемных помех // Журнал радиоэлектроники. 2016. №II. Режим доступа: http://jre.cplire.ru/jre/novl6/index.html.

2. Лернер И.М., Ильин Г.И. Об одной возможности увеличения скорости передачи при наличии дестабилизирующих факторов в системах связи, использующих взаимную интерференцию символов // Физика волновых процессов и радиотехнические системы, 20І7. №4. С. 24-34.

3. Лернер И.М. Метод оценки пропускной способности реальных каналов связи с многопозиционными фазоманипулированными сигналами при наличии межсимвольных искажений и его применение // Т-Comm: Телекоммуникации и транспорт. 2017. Том II. №8. С. 52-58.

4. Лернер И.М., Чернявский С.М. Оценка пропускной способности реальных каналов связи с АФМН-N-сигналами при наличии МСИ // Т-Сотm: Телекоммуникации и транспорт. 2018. Том 12. №4. С. 48-55.

5. Лернер И.М., Файзуллин Р.Р., Чернявский С.М. К вопросу повышения спектральной эффективности фазовых радиотехнических систем передачи информации, функционирующих при сильных межсимвольных искажениях // Известия высших учебных заведений. Авиационная техника. 2018. №I. C. $113-118$.

6. Лернер И.М., Фатыхов М.М., Ильин Г.И. Особенности функционирования каналов связи с АФМн-п-сигналами при использовании взаимно коррелированных символов // Физика волновых процессов и радиотехнические системы, 2019. №І. С. 36-49.

7. Лернер И.М. К вопросу оптимизации амплитудно-частотных характеристик каналов связи с ФМН-n-сигналами, построенных на основе теории разрешающего времени // Т-Сотm: Телекоммуникации и транспорт. 2019. Том I3. №9. С. 36-49.

8. Лернер И.М. О влиянии формы амплитудно-частотной характеристики на пропускную способность канала связи с памятью, использующего принципы теории разрешающего времени, с АФМн-N-сигналами // Т-Comm: Телекоммуникации и транспорт. 2019. Том 13. № 10. С. 45-59.

9. Кадушкин В.В., Фатыхов М.М., Зарипов Р.Ф. О достаточности полигауссовой аппроксимации произвольных вероятностных распределений в радиолиниях систем связи с подвижными объектами // Новые технологии, материалы и оборудование российской авиакосмической отрасли: Всероссийская научно-практическая конференция с международным участием, $10-12$ августа 2016 г.: Сборник докладов. Том 2. Казань: Изд-во Академии наук РТ, 20I6. Т.2. С. 52I-523.

І О. Козлов С.В. Новые смесевые подходы к проектированию радиоинтерфейса систем связи. Казань: ООО "Новое знание", 2014.132 с.

II. Файзуллин Р.P. Комплексный подход к решению задачи структурного синтеза мультипроцессорных устройств обработки сигналов мобильных инфокоммуникационных систем // Нелинейный мир, №2. Т. 9. М.: ЗАО "Издательство "Радиотехника", 201І. С. 78-85.

12. Файзуллин Р.Р., Кадушкин В.В., Зарипов Р.Ф. Полигауссовский алгоритм совместной демодуляции-декодирования в каналах мобильных систем связи // Нелинейный мир, №8. Т. 13. М.: ЗАО "Издательство "Радиотехника", 20I5. С. 4-9.

13. Свидетельство № 20176/5223. Программа для моделирования алгоритмов обработки сигналов в мобильных системах связи / Заявитель и патентообладатель ФГБОУ ВО "Казанский национальный исследовательский технический университет им. А.H. Туполева - KAИ" (RU). № 2017612066; заявл. 14.03.2017; зарегистр. 05.05.2017.

14. Чабдаров Ш.М., Трофимов А.Т. Полигауссовы представления произвольных помех и прием дискретных сигналов // Радиотехника и электроника, 1975. T. 20. №4. С. 734-745.

15. Чабдаров Ш.М., Файзуллин Р.Р., Надеев А.Ф., Рахимов Р.Х., Феоктистов А.Ю. Статистические модели и методы обработки сигналов в системах радиосвязи: Учебное пособие. Казань: Изд-во Казан. гос. техн. ун-та, 1997. 90 с.

16. Королев В.Ю. ЕМ-алгоритм, его модификации и их применение к задаче разделения смесей вероятностных распределений. Теоретический обзор. М.: ИПИ РАН, 2007. 94 с.

17. Надеев А.Ф., Подкурков И.А. Адаптивная оценка параметров распределения негауссовских помех на основе применения ЕМ-алгоритма и его модификаций // Нелинейный мир. 2015. № 8. Т. 13. С. 64-72.

\section{Информация об авторах:}

Зарипов Ренат Фаридович, ассистент кафедры НТвЭ, Казанский национальный исследовательский технический университет им. А.Н. Туполева - КАИ, Казань, Россия

Фатыхов Марат Монирович, ассистент кафедры НТвЭ, Казанский национальный исследовательский технический университет им. А.Н. Туполева - КАИ, Казанский национальный исследовательский технический университет им. А.Н. Туполева - КАИ, Казань, Россия 